\title{
Younger Dryas Comet 12,900 BP
}

\author{
Hermann G. W. Burchard \\ Department of Mathematics, Oklahoma State University, Stillwater, OK, USA \\ Email: skeptiker@icloud.com
}

How to cite this paper: Burchard, H.G.W. (2017) Younger Dryas Comet 12,900 BP. Open Journal of Geology, 7, 193-199. https://doi.org/10.4236/ojg.2017.72013

Received: December 28, 2016 Accepted: February 24, 2017 Published: February 27, 2017

Copyright $\odot 2017$ by author and Scientific Research Publishing Inc. This work is licensed under the Creative Commons Attribution International License (CC BY 4.0).

http://creativecommons.org/licenses/by/4.0/

\begin{abstract}
Deep troughs in Lake Superior support the hypothesis of Younger Dryas Boundary (YDB) comet impact 12,900 BP. The impact theory explains the megafauna extinction, a black mat across the Northern hemisphere, nanodiamonds, platinum and iridium, and the enigmatic Carolina Bays (CB). While the CB were thought to predate Clovis cultural remains, but this must now be seen as spurious as the $\mathrm{CB}$ occur on Long Island, an LGM terminal moraine \& on endglacial flood plains, according to Allen West. The CB sand rims are exceptionally pure quartz with large phenocrysts, and also they exude hydrogen $(\mathrm{H})$. This suggests origin from deep granitic plutons, the granite typically being oversaturated with silica. When the Russian Kola Peninsula Superdeep Borehole had reached $40,000 \mathrm{ft}, \mathrm{H}$ was boiling from the borehole. This $\mathrm{H}$ is among volatiles copiously dissolved in the mantle, from the primitive solar nebula. The granite is from the Lake Superior Province. Lakes Superior, Michigan, Huron \& Ontario have deep holes, reaching to below sea level. Bathymetry exhibits a $\sim 145 \mathrm{~km}$ circular contour in Eastern L. Superior, where deep troughs occur, eroded in breccias infilling impact explosion cavities many kms deep, as much as 15 to 35 $\mathrm{km}$, the comet fragments coming in from the NW, with the holes lined up along the trajectory. This was an oblique impact with an extremely low angle of incidence, so the ejected granite quartz sands ended up in the CB along the Eastern seaboard principally.
\end{abstract}

\section{Keywords}

Younger Dryas Comet Hypothesis, Great Lakes Comet Impact, Carolina Bays Quartz Sands

\section{Introduction}

During the last decade, the late Ice Age cooling event 12,900 yrs ago at the Younger Dryas boundary (YDB), with re-advance of continental ice sheets and megafauna extinction (incl. mammoth), has received prominent scientific attention, due to a series of publications by Richard Firestone, Lawrence Berkeley Nat. Lab., and 
his team of colleagues, claiming the discovery of a cosmic object impact that caused the YDB event [1] [2]. There still is ongoing scientific debate \& controversy followed by many people with great interest.

The public likewise may be greatly interested, I believe. Since the occasion of the Chelyabinsk meteorite fall that occurred on Feb. 15, 2013, many have been paying attention to cosmic object impacts threatening civilization, regardless of political ideology. This leads me to believe the readership of this journal may carry an inherent interest in such matters, linking outer space to our little, usually solitary planet. This is why I am motivated to comment on the YDB cosmic impact hypothesis of Richard Firestone \& his team: in the last few months and weeks, I have been very fortunate to learn several key aspects of the YDB events, in part by email exchange with some of the principals who graciously have answered my questions, and helped me to arrive at the new scenario presented in this paper, which I hope will remove any doubts about the YDB comet hypothesis. Special thanks are due for valuable information provided by my friends Allen West and Tim Harris. Final clue came from a science poster by Prof. Robert S. Regis and colleagues, N Michigan University, Marquette, MI [3].

\section{Review of Known Facts \& Logical Process of Inferences}

The image emerges of an enormous event to hit the continent of $\mathrm{N}$ America $12,900 \mathrm{BP}$, and to a lesser extent throughout large parts of Eurasia. Next, let us list the facts from a variety of sources that are known, \& thereupon enter into an orderly process of logical deduction $\&$ inference to arrive at our results. So then, here are the reasons and this is what we should believe that it happened.

\subsection{Mysterious Carolina Bays Challenge}

The cosmic object impact theory explains the megafauna extinction, a black mat across the Northern hemisphere, nanodiamonds, platinum and iridium, \& much, much more, in particular the enigmatic Carolina Bays (CB) predominantly found on the Eastern seaboard, elliptical ovals all oriented in a NW to SE direction (Figure 1). Bays are surrounded by rims composed of sand. These sometimes

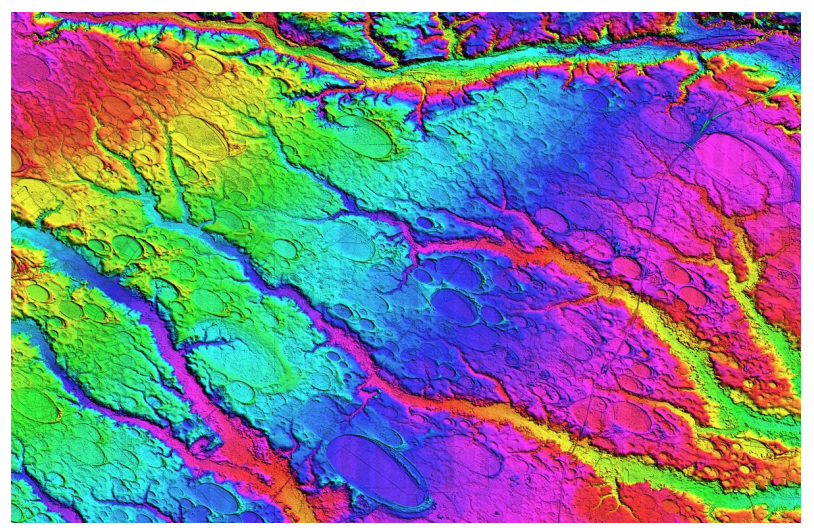

Figure 1. Laser Altimetry of the Carolina Bays (LIDAR), SW of Fayetteville, North Carolina. Photographer Michael Davias: http://epod.usra.edu/blog/2010/12/ 
form complete enclosures but often occur in form of a crescent. The number of $\mathrm{CB}$ is uncertain, perhaps $\sim 50,000$, possibly much greater, in the hundreds of thousands [4].

\subsection{Dating the Carolina Bays}

The $\mathrm{CB}$ were thought to predate the Clovis cultural remains, but this must now be seen as spurious, as the CB occur on Long Island, a Last Glacial Maximum (LGM) terminal moraine \& on end-glacial flood plains, according to Allen West, personal communication.

\subsection{Granitic Origin of CB Quartz Sands}

The CB sand rims are exceptionally pure quartz with large phenocrysts, and also they ooze hydrogen $(\mathrm{H})[4]$. This suggests origin from deep granitic plutons, the granite typically being oversaturated with silica. As to the $\mathrm{H}$ seepage, this can be understood from the Russian Kola Peninsula Superdeep Borehole. When the drill had reached 40,000 ft, $\mathrm{H}$ was boiling from the borehole. This $\mathrm{H}$ can only be from among volatiles of various kinds including methane \& other hydrocarbons that are copiously dissolved in the mantle, from the primitive solar nebula.

\subsection{Lake Superior Granite Province}

A possible source of granite is in the Lake Superior province, rich in ancient granite, which typically arises as plutons erupted from the Mohorovicic (Moho) discontinuity.

\subsection{Unusually Deep Holes in Great Lakes and Impact Cratering Hypotheses}

There are deep holes in four of the Great Lakes, Superior, Michigan, Huron \& Ontario, reaching to below sea level. No plausible mechanism of erosive glacial action can explain these. This has long been noted by the Firestone team as indicative of impact cratering. However, their main thesis was that aerial bursts of a comet occurred with fragments causing minor cratering in the Lakes (Figure 2). Geologist Robert Dietz, famous for discovering Sudbury, ON, as an astrobleme (from the nickel and other platinum group metal speckles in the rocks around the structure), also long ago already had contributed the conjecture that Lake Superior is an impact crater. ${ }^{1}$

\subsection{Carolina Bays Ejecta from YDB Comet}

The ejection of quartz sands toward the Atlantic East Coast would now seem to be the likely explanation of the CB enigma. This hypothesis suggests a comet arriving from the NW for an oblique impact, with the holes lined up along the trajectory, coming in at an extremely low angle of incidence, so the ejected granite quartz sands ended up in the $\mathrm{CB}$ along the Eastern seaboard principally. Fresh advance of ice sheets would have cleaned off ejecta from near the Great Lakes,

${ }^{1}$ Sankar Chatterjee, personal communication. 


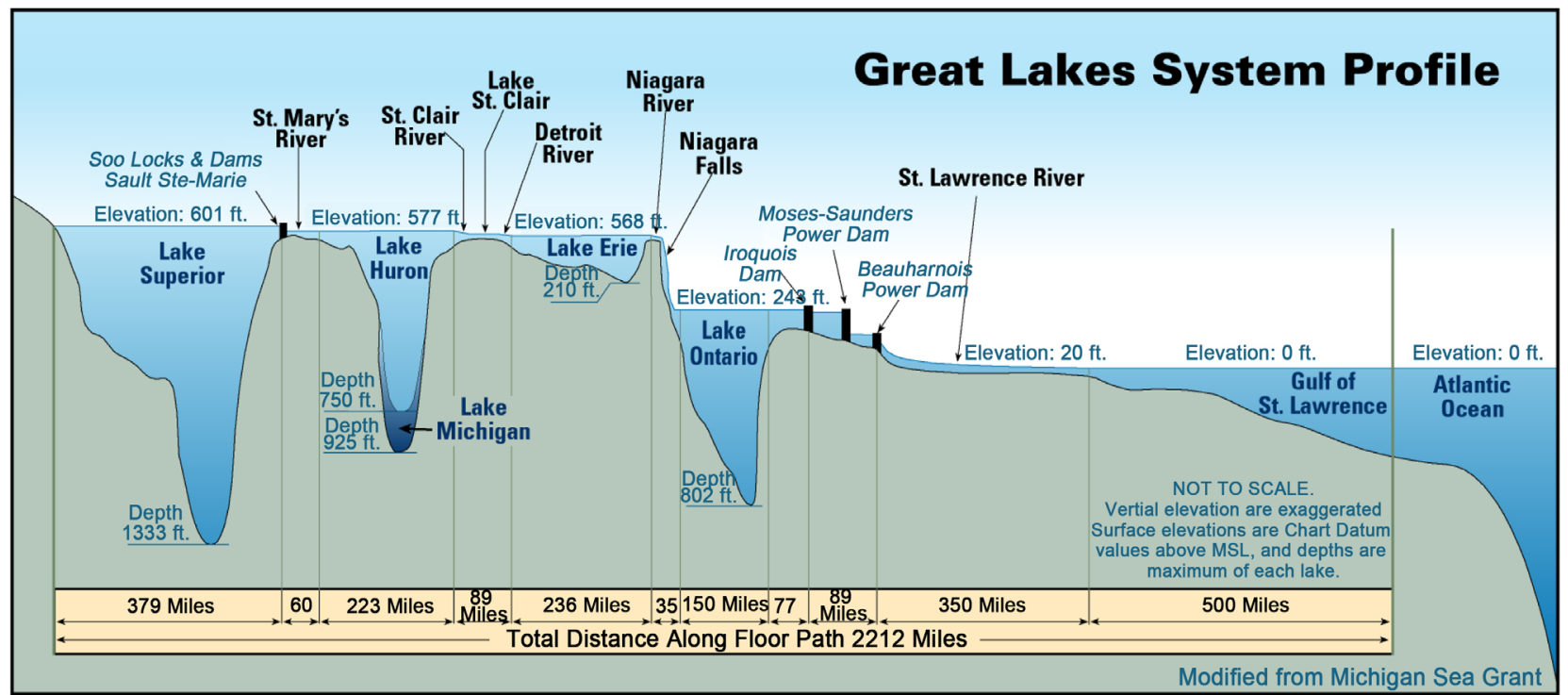

Figure 2. Deepest holes in great lakes. U.S. army corps of engineers.

with traces possibly mixed in with the till, or in terminal moraines. The Eastern peninsula of Upper Michigan is formed from sediments, perhaps ejecta.

\subsection{Multiple Comet Fragment Impacts}

The holes appear to lie on or near a straight NW-SE line. Comets are notoriously fragile so an incoming missile is liable to break up under "impact focusing," a kind of tidal force effect (recall 1994 when Comet SL9 broke into 23 pieces which later fell into planet Jupiter). This explains the four holes. Even Lake Erie appears to have been impacted, perhaps by a lesser fragment. There are numerous examples on Earth and other solar system bodies of crater alignments, as the separate frags are likely to impact near the projection of the approach trajectory.

\subsection{Deep Excavation of Granites by Impact Explosions}

Here, we claim excavation several $\mathrm{km}$ deep by comet fragments, the initial impact explosions perhaps reaching to near the Moho and ejecting quartz sands typically including phenocrysts and infused with $\mathrm{H}$ seeping up from the mantle.

\subsection{Large 145 km Diameter Crater in Lake Superior}

A circular contour of about $145 \mathrm{~km}$ diameter appears in Eastern Lake Superior bathymetry (Figure 3 ). Deep cavities, $\sim 1 / 10$ to $1 / 4$ of crater diameter deep are thought to be created initially by the impact explosion. For the L. Superior circular hole, this amounts to a cavity 15 to $35 \mathrm{~km}$ deep. This could be a complex multiring crater, with an outer wall of $145 \mathrm{~km}$ and an inner rim of $100 \mathrm{~km}$. Smaller craters appear $\mathrm{N}$ and $\mathrm{E}$, with partial overlap of contour lines.

\subsection{Initial Cavity Collapse}

Breccia almost immediately would have refilled collapsing initial cavities. 


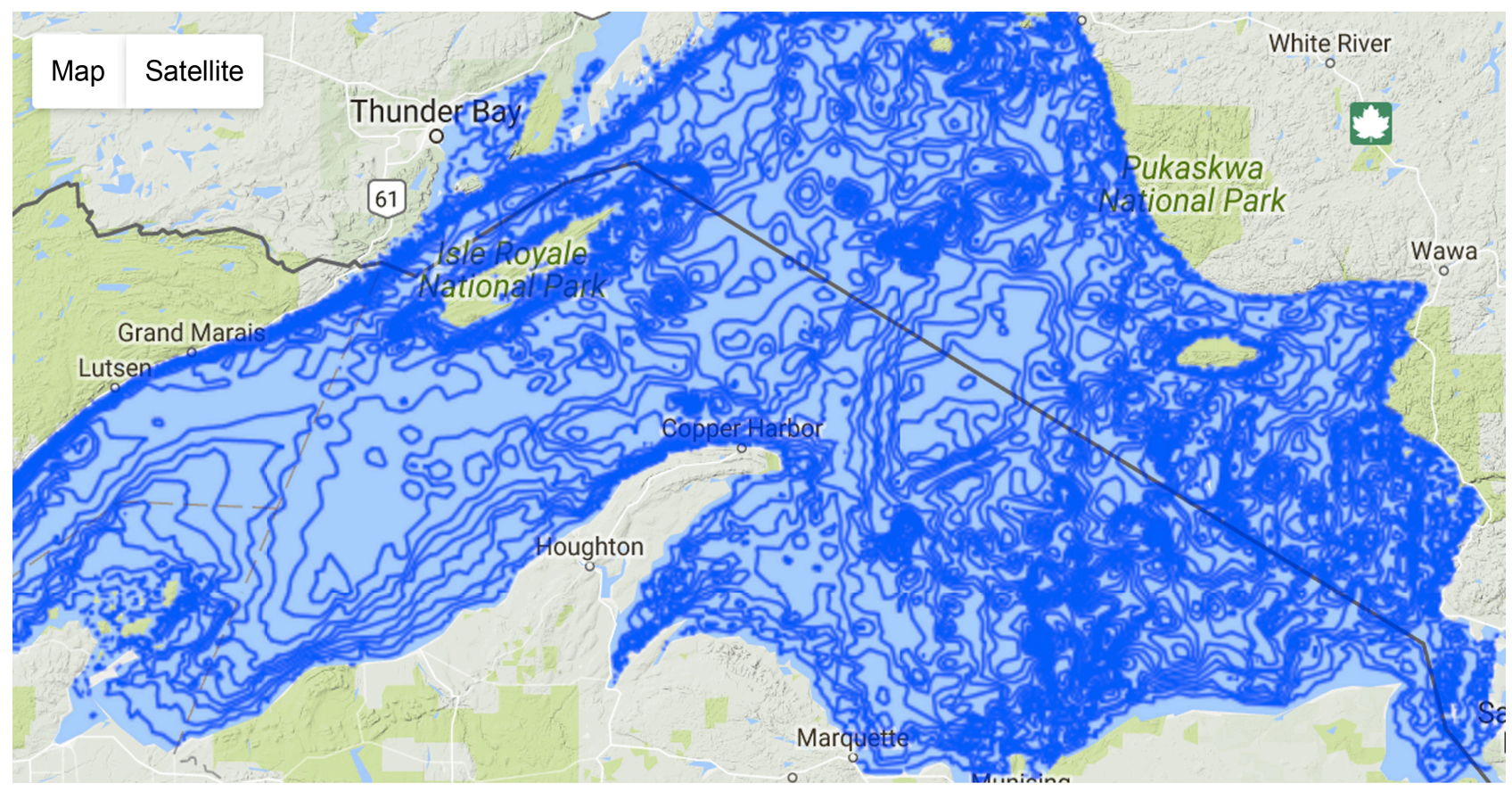

Figure 3. Lake Superior bathymetry showing $145 \mathrm{~km}$ circular contour in the deepest part, Eastern Lake. For troughs cut into breccias, cf. Figures below. Google Earth.

\subsection{Unusual $200 \mathrm{~m}$ Deep Trenches in Deep Holes}

The deep holes show scars in the form of valleys, channels or troughs. The maximally $200 \mathrm{~m}$ deep troughs or trenches show up clearly in satellite maps (Figure 4(a)). The above cited poster of Prof. Regis \& colleagues at N Michigan University [3] provides detailed data for the troughs or trenches \& geological insights lucidly explained. The following verbatim quotes are from this poster: "... unusually deep bedrock troughs in the eastern basin of Lake Superior," stating that these "trenches were formed by south-flowing subglacial streams... Our preliminary conclusion is that these trenches represent the normal drainage that develops near the margins of an ice lobe when is rests on erodible rock." The area described is coincident precisely with the $145 \mathrm{~km}$ circular contour seen in the bathymetry.

\subsection{Trenches Are Evidence for Breccia in Lake Bottoms}

Here, it is our hypothesis that the trenches are atop impact craters, typically filled by erodible breccias. The erosive power of subglacial water flowing need not have been high. No such trenches are in other parts of the lake floors (although shallow trenches covered by sediment have been found, perhaps brecciated on approach by the low angle impact), ergo we see our hypothesis of breccias from impact cavities refill confirmed. Caribou Island in its near-central position of the deep hole in Lake Superior appears in three of our figures. Very possibly, this is non-eroded remnant of the central uplift from the impact cratering event. The troughs or trenches also occur in three other Great Lakes, in the deep holes, presumably all cut into erodible breccias (Figure 4(b)). 

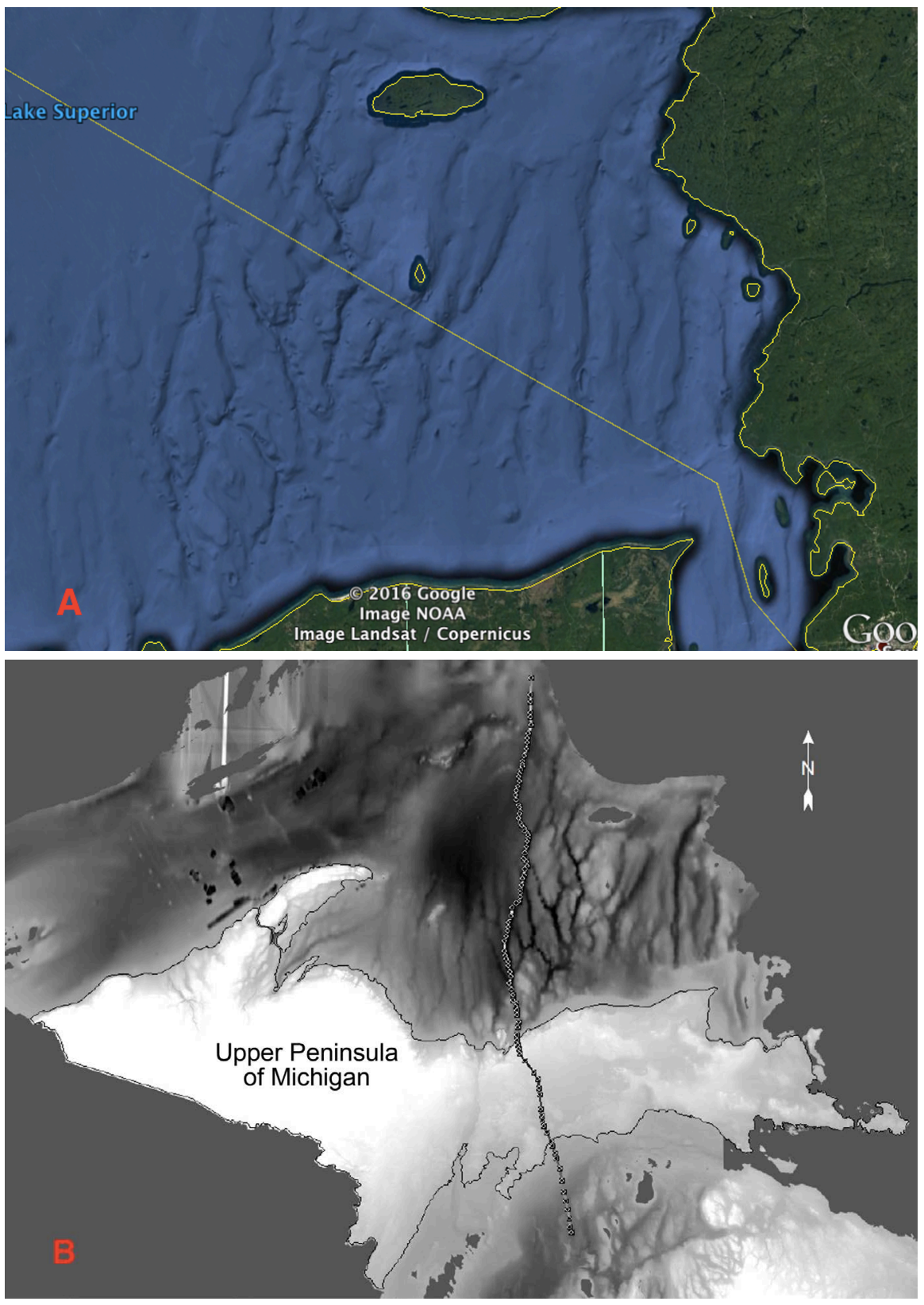

Figure 4. (A) Lake Superior, the deep hole, showing trenches cut into impact breccias. The diagonal line is the international boundary. Google Earth. (B) Lakes Superior \& Michigan East, showing trenches in lakes, Prof. R. Regis \& colleagues, poster [3].

\section{Conclusions}

Before the Deluge drowned the bared continental shelves of the last Ice Age over the course of several millennia, the great cataclysm of the Younger Dryas befell $\mathrm{N}$ America and much of Eurasia. It was caused by the YDB comet impact that created the Great Lakes. Of this, we here offer the first proof, albeit based on circumstantial evidence.

The impact excavated deep holes in four of the Lakes, Superior, Michigan, Huron and Ontario. Granitic ejecta in the form of exceptionally pure quartz sands \& hydrogen formed the Carolina Bays. Fragments of the comet along its trajectory, 
it seems, in form of a meteorite-causing debris trail fell as feu du ciel in much of the Northern hemisphere and left the black mat in its wake. Perhaps, impact volcanism from one of the fragments caused the Laach eruption in the Eifel Mountains, near Cologne (Laach is OHG for lake; the name Maria Laach dates to 1863; until 1863 the monastery was named Laach after the lake, not the other way round, as claimed by some). Both the YDB comet and the Laach eruption are dated to $12,940 \mathrm{BP}$, despite some later dates for the YDB stated in older papers (15 yrs. ago). Previously, the distinction volcano vs. ET impact was often argued. The fact that Yellowstone is impact caused [5] relegates this argument to the dustbin of science history.

\section{References}

[1] Firestone, R.B., et al. (2007) Evidence for an Extraterrestrial Impact 12,900 Years Ago that Contributed to the Megafaunal Extinctions and the Younger Dryas Cooling. Proceedings of the National Academy of Sciences USA, 104, 16016-16021. https://doi.org/10.1073/pnas.0706977104

[2] Kennett, J.P., et al. (2015) Bayesian Chronological Analyses Consistent with Synchronous Age of 12,835 - 12,735 Cal B.P. for Younger Dryas Boundary on Four Continents. Proceedings of the National Academy of Sciences USA, 112, E4344-E4353. https://doi.org/10.1073/pnas.1507146112

[3] Regis, R.S., Patterson, C.J., Wattrus, N. and Rausch, D. (2003) Relationship of Deep Troughs in the Eastern Lake Superior Basin and Large-Scale Glaciofluvial Landforms in the Central Upper Peninsula of Michigan. Poster in the Geological Society of America, North-Central Section-37th Annual Meeting, Kansas City, Missouri, 24-25 March 2003, Paper No. 19-10. http://esker.nmu.edu/images/GSA03-KC-POSTER-LEFT-3.pdf

[4] Zgonnik, V., et al. (2015) Evidence for Natural Molecular Hydrogen Seepage Associated with Carolina Bays (Surficial, Ovoid Depressions on the Atlantic Coastal Plain, Province of the USA). Progress in Earth and Planetary Science, 2, 31-46. https://doi.org/10.1186/s40645-015-0062-5

[5] Burchard, H.G.W. (2016) Meteorite Impact Origin of the Yellowstone Hotspot. Open Journal of Philosophy, 6, 412-419. https://doi.org/10.4236/ojpp.2016.64038

\section{Scientific Research Publishing}

Submit or recommend next manuscript to SCIRP and we will provide best service for you:

Accepting pre-submission inquiries through Email, Facebook, LinkedIn, Twitter, etc. A wide selection of journals (inclusive of 9 subjects, more than 200 journals)

Providing 24-hour high-quality service

User-friendly online submission system

Fair and swift peer-review system

Efficient typesetting and proofreading procedure

Display of the result of downloads and visits, as well as the number of cited articles

Maximum dissemination of your research work

Submit your manuscript at: http://papersubmission.scirp.org/

Or contactojg@scirp.org 